\title{
PROLIFERATION INHIBITORY ACTIVITY OF THE ACTIVE FRACTION MARINE SPONGE Cinachyrella sp. AGAINST CELL LINE T47D
}

\author{
Awik Puji Dyah Nurhayati ${ }^{1}$, Rarastoeti Pratiwi ${ }^{2}$, Subagus Wahyuono ${ }^{3}$, Istriyati \\ ${ }^{1}$ Biology Department, Mathematic and Natural Science Faculty, \\ Sepuluh November Institute of Technology Surabaya \\ ${ }^{2}$ Biology Faculty ,Gadjah Mada University, Yogyakarta \\ ${ }^{3}$ Pharmacy Faculty, Gadjah Mada University, Yogyakarta \\ awiknurhayati@gmail.com; rarastp@yahoo.com; subagus@bio.its.ac.id; istriyati@ugm.ac.id;
}

\begin{abstract}
Marine sponges Cinachyrella sp. (Family:Tetillidae) in Kukup beach, Kemadang Village, Tanjungsari District, Gunung Kidul, DIY were producing diversity secondary metabolites such as polyketides, alkaloids, peptide and terpene. The purpose of this study was investigated proliferation inhibitory activity of active fraction Cinachyrella sp. against cell line T47D. Sponges samples were collected manually from rocky substrate at depth $0.5 \mathrm{~m}$. The sponges was minced and extracted with $95 \%$ ethanol. The ethanol extract was partitioned sequentially with ethyl acetate. The extract ethyl acetate was fractionation with 4 organic solvent, in increasing order of polarity with vacuum liquid chromatography column (VLC) method. Doubling time method was applied to analyse the inhibition proliferative cell line T47D. Resulted showed ethyl acetate extract of Cinachyrella $\mathrm{sp}$. were 12 fractions and all tested fraction obtained by thin layer chromatography (TLC). Fractions that have the same value Rf grouped together to obtain 6 fractions. The fraction number 5 exhibited proliferation inhibitory activity to cell line T47D. The Rf value of active fraction number 5 were $0.125 ; 0.25$ and 0.437 . The active fraction 5 than isolation by preparative thin-layer chromatography (PTLC) was 5 isolate fractions preparative. The isolate fractions preparative number 5 exhibited proliferation inhibitory activity against cell line T47D. Fraction which determined by cerium sulfate and results was expressed terpene and alkaloid.
\end{abstract}

Key words: Cinachyrella sp., Doubling time method, proliferation inhibitory activity.

\section{INTRODUCTION}

Cancer is the fourth leading cause of death after stroke, hypertension and diabetes (Ullah \& Aatif, 2009). In Indonesian patients of cancer also tended to increase (Tjindarbumi \& Mangunkusumo, 2002). Data Riskesdas reported that in 2007 there were 100 new cancer patients than 100,000 residents. Many attempts have been made to overcome cancer. In America and Europe is estimated $65 \%$ of cancer drugs derived from natural materials commercially (Wei et al., 2007). Derivate of bioactive compound from natural products have specific targets and has no side effects (Iwamaru et al., 2007). Sponges as sessil animals, filter feeders have a strategy physiology, reproduction and defense mechanisms are effective against bacterial infections, fungi, viruses and predators (Brackman \& Daloze, 1986), space competition with other organisms (Schupp et al., 2009) marine and defense against pathogens (Muller et al., 2004) by producing secondary metabolites (Bell, 2008). Kukup beach, village Kemadang, Tanjungsari District, Gunung Kidul, Yogyakarta has a diverse marine life. The lectin proteins, which we refer to as the Cinachyrella galectins (CchGs), were identified as the active principles in an aqueous sponge extract that modulated the function of mammalian ionotropic glutamate receptors (Ueda et al., 2013). In the test anticancer ethanol fraction Cinachyrella sp. against cancer cells WiDr showed arrest results in G0-G1 phase was $57.31 \%$ (Nurhayati et al., 2011). In the cytotoxicity assay HeLa cancer

ISSN 2413-0877 (C) 2015 The Authors.

Published by KnowledgeE Publishing Services This is an open access article under the CC BY-NC-ND license (http://creativecommons.org/licenses/by-nc-nd/4.0)

Selection and Peer-review under responsibility of the 3rd ICBS-2013

Doi http://dx.doi.org/10.18502/kls.v2i1.243 
cells, T47D, WiDr and normal Vero cells obtained results targets cancer cells ethyl acetate fraction sponge Cinachyrellasp. is WiDr at $253.548 \mathrm{ug} / \mathrm{ml}$ (Nurhayati et al., 2012). Ethyl acetate fraction has several active fractions are not known WiDr cell proliferation inhibition activity.

\section{MATERIALS AND METHODS}

Sponge Cinachyrella sp. sampling from Kukup beach, village Kemadang, Tanjungsari District, Gunung Kidul, Yogyakarta at intertidal areas by way of direct collection. Sponge inserted at plastic bag and stored in the icebox temperature of $5^{\circ} \mathrm{C}$. Sponge mass of macerated with $96 \%$ ethanol for 2-3 days. Ethanol extract partitioned with ethyl acetate. The filtrate was fractionated by vacuum liquid chromatography column. The solvent used was $\mathrm{n}$ hexane $(100 \%)$, n-hexane: ethyl acetate $(9: 1 ; 8: 2 ; 7: 3 ; 6: 4 ; 5: 5 ; 4: 6 ; 3: 7 ; 2: 8 ; 1: 9)$, ethyl acetate $(100 \%)$ and methanol (100\%). Fractionation results obtained 12 fractions. Fractions showed the same Rf value combined to obtain 6 fractions. Further proliferation inhibition test with Double-time method. Variations are tested concentrations of 600, 300 and 150 $\mu \mathrm{g} / \mathrm{mL}$ for fraction and $25,50,100 \mu \mathrm{g} / \mathrm{mL}$ for doxorubicin. The most active fraction was isolated by preparative thin layer chromatography and proliferation inhibition test with a concentration of $62.5 ; 125 ; 250 \mu \mathrm{g} / \mathrm{mL}$.

\section{RESULTS AND DISCUSSION}

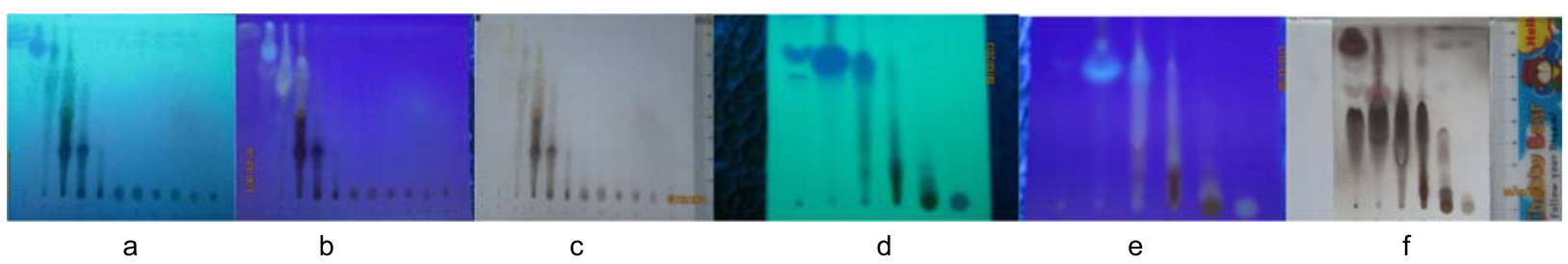

Figure 1. Test results of thin layer chromatography (TLC) of 12 fractions results column, UV 254 (a), UV 366 (b), (c) after using cerium sulfate (d). Test results of thin layer chromatography (TLC) of 6 fractions results column, UV 254 (d), UV 366 (e) and after using cerium sulfate (f).
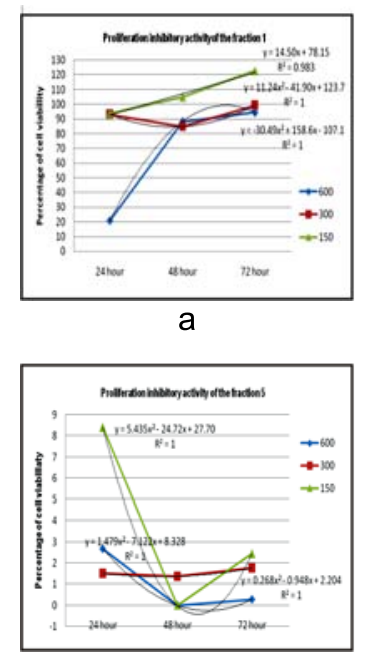

e

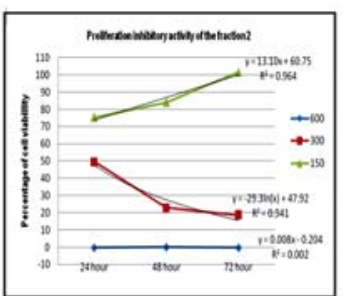

b

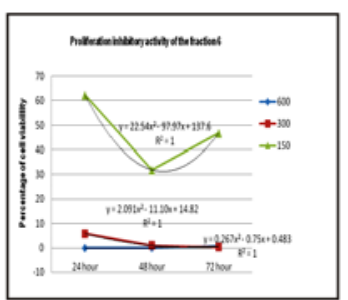

f

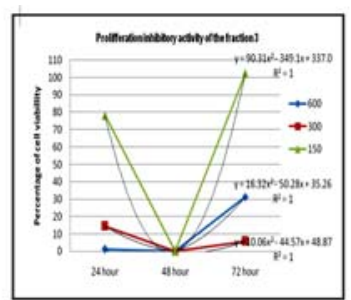

C

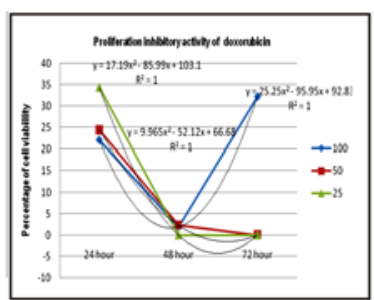

g

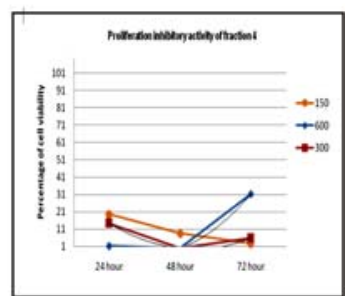

d

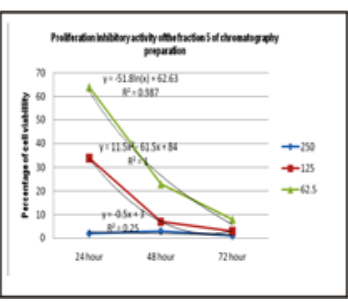

$\mathrm{h}$

Figure 2. Test results WiDr cell proliferation inhibition of fraction 1 (a), fraction 2 (b), fraction 3 (c), fraction 4 (d), fraction $5(\mathrm{e})$, fraction $6(\mathrm{f})$, doxorubicin $(\mathrm{g})$ and fraction 5 of preparative chromatography (h). 
Doubling time test was conducted to determine the effect of marine sponge Cinachyrella sp. fraction of the cancer cells WiDr. Concentrations used were 600,300 and $150 \mu \mathrm{g} / \mathrm{mL}$ for column fractions; $25,50,100 \mu \mathrm{g} / \mathrm{mL}$ for doxorubicin and $62.5 ; 125 ; 250 \mu \mathrm{g} / \mathrm{mL}$ for KLTP fraction with incubation time 24, 48 and 72 hours. This test is performed with MTT method. Doubling time test results can be seen in Figure 2. It appears that after administration of fraction and incubated for 24 hours a decline in the percentage of living cells. The highest decline seen in fraction 5 , which is at a concentration of $300 \mu \mathrm{g} / \mathrm{mL}$. At 48 hours of incubation, the concentration fraction granting 600 and $150 \mathrm{mg} / \mathrm{mL}$ showed a decrease in the percentage of live cells. At 72 hours of incubation, the increase percentage of WiDr cancer cells. This is presumably because of the time needed by cancer cells WiDr cells to complete one cycle is very short is 15 hours. So at 72 hours of incubation, the number of population is very high WiDr cells. Giving fraction sponge Cinachyrella sp. and doxorubicin can not inhibit the growth of cancer cells WiDr. One of the characteristics of WiDr cells is the expression cyclooxygenation-2 (COX-2) is a high spur WiDr cell proliferation (Palozza et al., 2005).

Differences in the ability of marine sponge fraction activity Cinachyrella sp. against cancer cells WiDr because fractions have different compound components (Jenei et al., 2009). Fraction 5 has a value of $\operatorname{Rf} 0.125 ; 12: 25$ and 0437 and is a group of terpenes and alkaloids. Bioactive compounds found in marine sponges Cinachyrella sp. among others cinachyramine (Shimagawa et al., 2006), enigmasole A (Oku et al., 2010). Sponge secondary metabolites are influenced by water conditions, and the type of sponge symbiont organisms (Larghi et al., ;2008). Positive control used is doxorubicin. Toxicity of doxorubicin because intercalation with DNA, forming a tripartite complex with topoisomerase II inhibition and DNA causing cell cycle and stopped at the G1 and G2 phases (Gewirtz, 1999).

\section{CONCLUSION}

The fraction number 5 exhibited proliferation inhibitory activity to cell line T47D. The isolate fractions preparative number 5 exhibited proliferation inhibitory activity against cell line T47D. Fraction which determined by cerium sulfate and results was expressed terpene and alkaloid.

\section{REFERENCE}

Bell, J. J. 2008. Review The functional roles of marine sponge. J. Estuarine, Coastal and Shelf Scienc. Vol. 79. Pp: 341-353.

Brackman, J. C., and D. Doloze. 1986. Chemical defence in sponges. Pure \& Appl. Chem. Vol 58 93): 357-364.

Gewirtz. 1999. Apo Review Introduction to Apoptosis.

Iwamaru, A., E. Iwado, and S. Kondo. 2007. Eupalmarea acetate, a novel anticancer agents from Caribbean gorgonian octocorals, induces apoptosis in malignant glioma cells via the c-jun NH2-terminal kinase pathway. Molecular Cancer Therapeutics. 6:184-192.

Jennei, R.I., and E. Meiyanto. 2009. Co-application of chemotherapy ethyl acetate fraction ethanolic leaf extract of continued life (Gynura procumbens (Lour) Merr on kanker payudara MCF-7 cells. Magazine Pharmaceutical Sciences. Vol. VI, No.3: 132-141. 
Larghi, E., B. Obrist, and T. Kaufman. 2008. "A Formal Total Synthesis of The Marine Alkaloid aaptamine". Tetrahedron. Volume 64, Issue 22

Muller, W., G.L.P. Grebenjuk, H.C. Schroder, F. Brummer, U. Hentschel, I.M. Muller, H.J. Breter. 2004. Review. Sustainable Production of Bioactive Compounds by Sponges-Cell Culture and Gene Cluster Approach: A Review Marine Biotechnology. 6: 105-117.

Oku, N., K. Takada, R.W. Fuller, J.A. Wilson, M.L. Peach, L.K. Pannell, J.B. McMohan, and K.R. Gustafson. 2010. Isolation, Structural Elucidation and Absolute Stereochemistry of Enigmazole A, a Cytotoxic Phosphomacrolide from the Papua New Guiena Marine Sponge Cinachyrella enigmatica. Journal American Sociality, 132: 10278-10285.

Shimagawa, H., S. Kuribayashi, T. Teruya, K. Suenaga, and H. Kigoshi. 2006. Cinachyramine, the novel alkaloid possessing a hidrazone and two aminals from Cinachyramine sp. Tetrahedron Letters, 47:1409-1411.

Nurhayati, A.P.D., R. Pratiwi, B. Wahyuono, Istriyati. 2011, Anticancer studies with Cellular Approaches And Sea Sponge Conservation Efforts In Tanjungsari Cinachyrella sp, Gunung Kidul. Research grant program berbasis EfSD IMHERE Faculty of Biology, Gadjah Mada University.

Nurhayati, A.P.D., R. Pratiwi, B. Wahyuono, Istriyati. 2012, Anticancer activity Cinachyrella sp Sea Sponge In Tanjungsari, Gunung Kidul. Doctoral grant. ITS.

Palozza, T.B.P., S. Serini, N. Maggiano, P. Giuseppe, and F.O. Ranelletti. 2005. SteadyState and Heregulin-a-Induced COX-2 Pathways in Colon Cancer Cells, J.Nutr. 135:129136.

Perkasa, D.P., and A. Budiyanto. 2010. Isolation and antibacterial activity of sponge Cinachyrella sp. Laporan Penelitian Center for the Application of Isotope and Radiation Technology.

Schupp, P. J., C.K. Schupp, S. Whitefield, A. Engemann, S. Rohde, T. Heimsceidet, J. Pezutto, T.P. Kondratiuk, E.J. Park, L. Marler, B. Rostom, and A.D. Wright. 2009. Cancer Chemopreventive and Anticancer Evaluation of Extracs and Fractions from Marine Macro and Micro-organism Collected from Twilight zone Waters Around Guam. Nat. Prod. Commun. 4(12): 1717-1728.

Tjindarbumi, D., and R. Mangunkusumo. 2002. Cancer in Indonesia, Present and Future. Japan Journal of Clinical Oncology. 32 (supplement): 17-21.

Ullah, M.F., and M. Aatif. 2009. Hot Topic. The footprints of cancer development : cancer biomarker. Cancer Treatment Reviews. 35: 193-200.

Watanadilok, R., P. Sonchaeng, A. Kijjoa, A.M. Damas, L. Gales, A.M.S. Silva, and W. Herz. 2001. Tetillapyrone and Nortetitllapyron, Two Unusual Hydroxipyan 2-ones from the Marine Sponge Cinachyrella japonica. J. Nat. Prod. 64: 1056-1058. 